\title{
Correction to: Epigenetic signatures associated with imprinted paternally expressed genes in the Arabidopsis endosperm
}

Jordi Moreno-Romero ${ }^{1,2}$, Gerardo Del Toro-De León², Vikash Kumar Yadav², Juan Santos-González² and Claudia Köhler ${ }^{2^{*}}$

\section{Correction to: Genome Biol \\ https://doi.org/10.1186/s13059-019-1652-0}

Following publication of the original article [1], the authors reported that Additional file 4, "Table S5. Parentof-origin RNAseq dataset of 4 DAP INTACT-purified endosperm of Col $\times$ Ler reciprocal crosses" had the following error:

- Column 6, labeled as "Reads_Mat_Ler", should say "Reads_pat_Col".

- Column 7, labeled as "Reads_pat_Ler", should say "Reads_mat_Ler".

The updated Additional file 4 is published in this correction.

\section{Additional file}

Additional file 4: Table S5. Parent-of-origin RNAseq dataset of 4 DAP INTACT-purified endosperm of Col $\times$ Ler reciprocal crosses. (XLSX $820 \mathrm{~kb}$ )

\section{Author details}

${ }^{1}$ Present Address: Centre for Research in Agricultural Genomics (CRAG),

CSIC-IRTA-UAB-UB, Campus UAB, Bellaterra, Barcelona, Spain. ${ }^{2}$ Department of Plant Biology, Uppsala BioCenter, Swedish University of Agricultural Sciences and Linnean Center for Plant Biology, Uppsala, Sweden.

Published online: 02 September 2019

\section{Reference}

1. Moreno-Romero, et al. Epigenetic signatures associated with imprinted paternally expressed genes in the Arabidopsis endosperm. Genome Biol. 2019;20:41 https://doi.org/10.1186/s13059-019-1652-0.

\footnotetext{
* Correspondence: claudia.kohler@slu.se

${ }^{2}$ Department of Plant Biology, Uppsala BioCenter, Swedish University of

Agricultural Sciences and Linnean Center for Plant Biology, Uppsala, Sweden
}

(c) The Author(s). 2019 Open Access This article is distributed under the terms of the Creative Commons Attribution 4.0 International License (http://creativecommons.org/licenses/by/4.0/), which permits unrestricted use, distribution, and reproduction in any medium, provided you give appropriate credit to the original author(s) and the source, provide a link to the Creative Commons license, and indicate if changes were made. The Creative Commons Public Domain Dedication waiver (http://creativecommons.org/publicdomain/zero/1.0/) applies to the data made available in this article, unless otherwise stated. 